\title{
Volhoubare ontwikkeling: die groen bril
}

Dic ruimteprogram en ruimtereise, in die besonder, het grootliks tot die skepping van nuwe denkbeclde bygedra. Vanuit die ruimte is die aarde as ' $n$ geïsolecrde entiteit gesien. Die besef dat die lewensruimte en -middele van die mens (aarde) beperk is, het grootliks tot 'n algemene bewuswording van die gevaar verbonde aan die onverantwoordelike eksploitering van die aarde en sy hulpbronne bygedra. Die dinamiese karakter van hierdie nuwe denkbeeld word duidelik deur die ontwikkeling daarvan oor die afgelope paar dekades weerspieël. Die oordeelkundige benutting van basiese grondstowwe (lug, water en grond) het as vertrekpunt gedien. Besoedeling van hierdie abiotiese komponente is reeds in die vroe sewentigerjare as onaanvaarbaar beskou. Op natuurlike wyse is hierdie eng beskouing spoedig uitgebrei om ook die biotiese en later die kulturele omgewing in te sluit

Hierdie nuwe denkbeeld het verskeie wetenskaplike en tegnologiese veranderings genoodsaak. Wetenskaplike en industriële prestasies kon nie langer net aan maksimum opbrengs (wins) gemeet word nie. Die produk (proses) word ook in terme van sy "omgewingsvriendelikheid" beoordeel. Vir toegang tot monetêre fondse van potensicel groot beleggers (soos die Wêreldbank) word vereis dat aan sekere omgewingsvereistes voldoen word. Produkte wat op die internasionale mark gerig is, moet aan "groen vereistes" voldoen. Maatskappye en industrieë moet tot aan die einde van 'n produk se leeftyd daarvoor verantwoordelikheid aanvaar. Daar moet 'n totale kwaliteitsbenadering gevolg word waarvolgens die omgewing as die voorsiener, maar ook ontvanger van die produk gesien word. Hiervolgens is die omgewing ook die uiteindelike "kliënt" van die produk en moet dit daarvoor aanvaarbaar wees. Die haalbaarheid, al dan nie, daarvan word deur die omgewingsprestasies van individuele verskaffers en onderlinge kompetisie tussen alternatiewe substitute bepaal. Binne die raamwerk van totale kwaliteit word minder omgewingsgunstige produkte deur owerhede belas, om sodoende moontlike ekonomiese voordele teen te werk. Die belasting op sekere plastiekgebaseerde produkte in Amerika is 'n tipiese voorbeeld hiervan.

'n Holistiese benadering word dus vir die bestuur van "ruimteskip aarde" vereis. Die mens (as kulturele wese) se aktiwiteite moet in harmonie met die abiotiese en biotiese verskeidenheid en beperkinge van die "ruimteskip" bestuur word. Elke komponent van die werklikheid het hierdeur 'n nuwe (verhoogde) waarde gekry. Die priorisering van die verskillende komponente het meteens 'n baic gekompliseerde opdrag geword. Die omgewing as 'n funksionele eenheid is baie meer werd as sy afsonderlike komponente en moet so bewaar word. Die mens, as bestuurder van hierdie werklikheid, moet noodgedwonge al sy aktiwiteite in heroorweging neem. Die dilemma dat die mens, om te kan lewe, noodwendig 'n impak op hierdie werklikheid moet hê, het gelei tot die besef dat dic mens nie die omgewing kan bestuur nic - hy kan alleenlik maar sy aktiwiteite in ' $n$ bepaalde ruimtelike en tydsomgewing bestuur. Alle nenslike aktiwiteite moet egter deur 'n "groen bril" beskou word. Omgewingsbewaring is nie meer die vestiging van 'n wildkamp nic, maar die integrering van alle menslike aktiwiteite met die totale omgewing op 'n verantwoordelike wyse.

Ten einde aan hierdie nuwe eise te voldoen, het vereis dat die mens 'n multidissiplinêre analise en interdissiplinêre sintese van die impak van sy aktiwiteite moes maak. Eie aan die aard van gevestigde opleidingspatrone, is dit veral moeilik vir natuurwetenskaplikes en tegnoloë om binne so 'n wydomskryfde doel of raamwerk te funksioneer. Die "pyp-" of "tonnel-visie" waarvolgens natuurwetenskaplike navorsing tradisioneel bedryf is (doelgerig, afgestem op 'n spesifieke resul taat), is moeilik vereenselwigbaar met die praktiese verwagtinge en vereistes van dié nuwe denkbeeld. As opgeleide spesialis moet die wetenskaplike homself nou heroriënteer om die breëre samehang raak te sien en die nuwe inligting met voorafgestelde doelwitte te integreer. As nietige en beperkte wese stel hierdie eis 'n groot uitdaging aan die moderne wetenskaplike. In die lig van die vereiste gespesialiseerde kennis van die natuurlike sowel as die industriële en kulturele omgewing, word die bestaan van 'n "omgewingswetenskaplike" sterk bevraagteken. 'n Persoonlike mening is dat hierdie eis slegs binne groepsverband hanteer kan word.

Volhoubare ontwikkeling het ' $n$ eis van die tyd geword. Die beperktheid van die aarde en die mens is hierdeur opnuut uitgewys. Dit vereis 'n nuwe of herharmonisering van die menslike leefwyse met sy omgewing. Wetenskaplikes het nie alleenlik 'n groot rol hierin te speel nie, maar ook 'n groot verantwoordelikheid ten opsigte van die nakoming van hierdie eis.

J.J. PIENAAR 